\title{
2 tipo kvèpavimo takų uždegimas ir jo slopinimas biologiniais vaistais sergant astma ir lètine obstrukcine plaučių liga
}

\author{
TYPE 2 AIRWAY INFLAMMATION AND INHIBITION OF BIOLOGICAL DRUGS IN \\ ASTHMA AND CHRONIC OBSTRUCTIVE PULMONARY DISEASE
}

\author{
JOLITA PALAČIONYTĖ, KĘSTUTIS MALAKAUSKAS \\ LSMU MA Pulmonologijos klinika
}

\begin{abstract}
Santrauka. Astma ir lètinė obstrukcinė plaučių liga (LOPL) yra uždegiminės kvėpavimo takų ligos, kurių paplitimas visame pasaulyje didejja. Kiekvienai iš šių ligų būdingas heterogeniškumas, tai yra ne tik skirtinga ligos klinikinè eiga, bet ir ligos patogenezė bei atsakas ị gydymą. Suprasti astmos ir LOPL heterogeniškumą, nustatyti ligos fenotipą ir endotipą ypač svarbu siekiant individualizuoti šių ligų gydymą. Pastaruoju metu išskirtinis dèmesys skiriamas 2 tipo (angl. type 2) kvejpavimo takų uždegimui, kuriam būdinga eozinofilija. 2 tipo kvèpavimo takų uždegimo nepakankamas valdymas lemia sunkesnę ligos eigą, atsparumą vaistams, dažnus ligos paūmèjimus ir blogesnę gyvenimo kokybę. Nemažai gerai žinomų biologinių žymenų yra susieti su 2 tipo kvejpavimo takų uždegimu, o jų panaudojimas klinikinejje praktikoje yra ypač svarbus. Šioje apžvalgoje pateikiami apibendrinti duomenys apie 2 tipo kvejpavimo takų uždegimo išsivystymo kelius, biologinių žymenų svarbą ir poreiki, naujausias prieš 2 tipo kvejpavimo takų uždegimą nukreiptas gydymo galimybes.

Reikšminiai žodžiai: 2 tipo kvèpavimo takų uždegimas, biologiniai žymenys, astma, LOPL, biologiniai vaistai.

Summary. Asthma and chronic obstructive pulmonary disease are inflammatory airways diseases with an increasing prevalence worldwide. Each of these diseases is characterized by heterogeneity, that is, not only the different clinical course of the disease but also the pathogenesis of the disease and the response to treatment. To understand the heterogeneity of asthma and COPD, identify the phenotype of the disease and the endotype is particularly important to individualize the treatment of these diseases. Recently, special attention has been paid to type 2 airway inflammation, which is characterized by eosinophilia. Insufficient management of type 2 airway inflammation results in a severe course of illness, resistance to treatment, frequent exacerbations of the disease, and is associated with worse quality of life. A number of well-known biomarkers are associated with type 2 airway inflammation, and their use in clinical practice is essential. This review provides the summarized data on the pathways of the development of type 2 airway inflammation, the importance and need for biomarkers, the latest treatment options for type 2 airway inflammation.
\end{abstract}

Keywords: type 2 airway inflammation, biomarkers, asthma, COPD, biological drugs.

DOI: https://doi.org/10.37499/PIA.761

\section{IVADAS}

Astma ir lètinè obstrukcinè plaučių liga (LOPL) yra vienos iš labiausiai paplitusių lètinių ligų ir vienos iš dažniausių mirties priežasčių pasaulyje. Tai itin opi visuomenès sveikatos problema, dèl kurios ne tik panaudojama nemaža dalis sveikatos priežiūrai skiriamų lèšų, tačiau ir prarandamas sergančiojo produktyvumas bei darbo našumas $[1,2]$. Astmos ir LOPL gydymas ilgą laiką nesikeite. Manoma, kad tai sąlygojo gana lèta šios srities mokslo pažanga. Astmos ir LOPL gydymo gairèse rekomenduota gydymą parinkti remiantis ligos klinikine eiga bei sunkumu. Tik vèliau pastebejus, kad kai kuriems sergantiesiems būdingi dažni ligos paūmèjimai, pradèta domètis šių ligų patogeneze, kvèpavimo takų uždegimo tipų charakteristikomis, o tai sąlygojo geresni supratimą apie astmos ir LOPL heterogeniškumą. Taip daugiau nei prieš 10 metų atsirado fenotipo ir endotipo sąvokos [3, 4]. Fenotipu apibrèžiamos ligos klinikinès išraiškos, o endotipu - patofiziologiniai mechanizmai ląsteliniame ir molekuliniame lygmenyje. Individualizuotas šių ligų gydymas turi būti parenkamas ne tik pagal klinikinę eigą, bet atsižvelgiant ir ị endotipą [5].

Lètinis kvèpavimo takų uždegimas yra betarpiškai susijęs su astmos ir LOPL patogeneze ir laikomas vienu iš esminių patofiziologinių mechanizmų. Pagal vyraujantị uždegimo patogenezinị kelią ir jame dalyvaujančius citokinus išskiriami 2 tipo ir ne 2 tipo (angl. non-type 2) endotipai [6-8], o vertinant skrepliuose vyraujančių ląstelių kiekį - eozinofilinis, mišrus granuliocitinis, neutrofilinis ir paucigranuliocitinis endotipu potipiai (1 lentelè) [9]. 


\section{Moksliniai darbai ir apžvalgos}

Sergantiesiems astma dažniausiai nustatomas 2 tipo kvėpavimo takų uždegimas [10]. Kalbant apie sergančiuosius LOPL, ilgą laiką manyta, kad jų kvèpavimo takuose vyrauja neutrofilinis uždegimas ir tik vèliau pastebèta, kad maždaug 10-40 proc. atvejų kraujyje ir kvėpavimo takuose aptinkamas didesnis eozinofilų kiekis [4]. Tai leido daryti prielaidą, kad daliai sergančiųjų LOPL taip pat būdingas 2 tipo imuninis atsakas ir 2 tipo kvèpavimo takų uždegimas.

2 tipo kvèpavimo takų uždegimas apibrèžiamas kaip 2 tipo citokinų lemiamas uždegimas, kuriam būdingas padidèjęs eozinofilų kiekis - eozinofilija. Dèl šios priežasties dažnai galima išgirsti „eozinofilinio uždegimo“ terminą, o pagal tai ligos dažnai vadinamos eozinofiline astma ir eozinofiline LOPL. 2 tipo kvépavimo takų uždegimas gali vykti dviem skirtingais patogeneziniais keliais - per Th2 (angl. Thelper cells type 2, Th2) arba igimtas 2 tipo limfoidines ląsteles (angl. type 2 innate lymphoid cells, ILC2). Abiejų patogenezinių kelių aktyvinimui būtini citokinai - interleukinas (IL)-33, IL-25 ir užkrūčio stromos limfopoetinas (angl. thymic stromal lymphopoietin, TSLP). Šie citokinai inicijuoja tarpląstelinio signalo perdavimą $\mathfrak{i}$ Th2 ir ILC2, todèl vadinami aliarminais. 2 tipo citokinams priklauso IL-4, IL-5, IL-6, IL-9, IL-10, IL-13. Pabrèžtini IL-4, IL-5 ir IL13, nes šių citokinų funkcija ypač svarbi inicijuojant uždegimini atsaką, T limfocitų pagalbininkų (angl. Thelper cells type 2, Th2) ląstelių ir eozinofilų vystymąsi [11]. Atpažinti 2 tipo kvèpavimo takų uždegimą padeda 2 tipo kvėpavimo takų uždegimo biologiniai žymenys: kraujo eozinofilų kiekis, skreplių eozinofilų kiekis, IgE kiekis kraujo serume, $\mathrm{Fe}_{\mathrm{NO}}$ kiekis iškvepiamame ore ir periostino kiekis kraujo serume [12]. Atlikta daugelis tyrimų, kurie parode šių biologinių žymenų svarbą ne tik sergant astma, bet ir LOPL. 2 tipo kvėpavimo takų uždegimas pasireiškia intensyvesniais ligos simptomais, sunkesne ligos eiga, dažnesniais ir sunkesniais ligos paūmèjimais, o visa tai blogina gyvenimo kokybę. Taip pat paskatino kurti ir išbandyti naujas eozinofilinès astmos ir LOPL gydymo galimybes $[13,14]$.

Šiame straipsnyje apžvelgsime 2 tipo kvẻpavimo takų uždegimo vystymosi kelius,

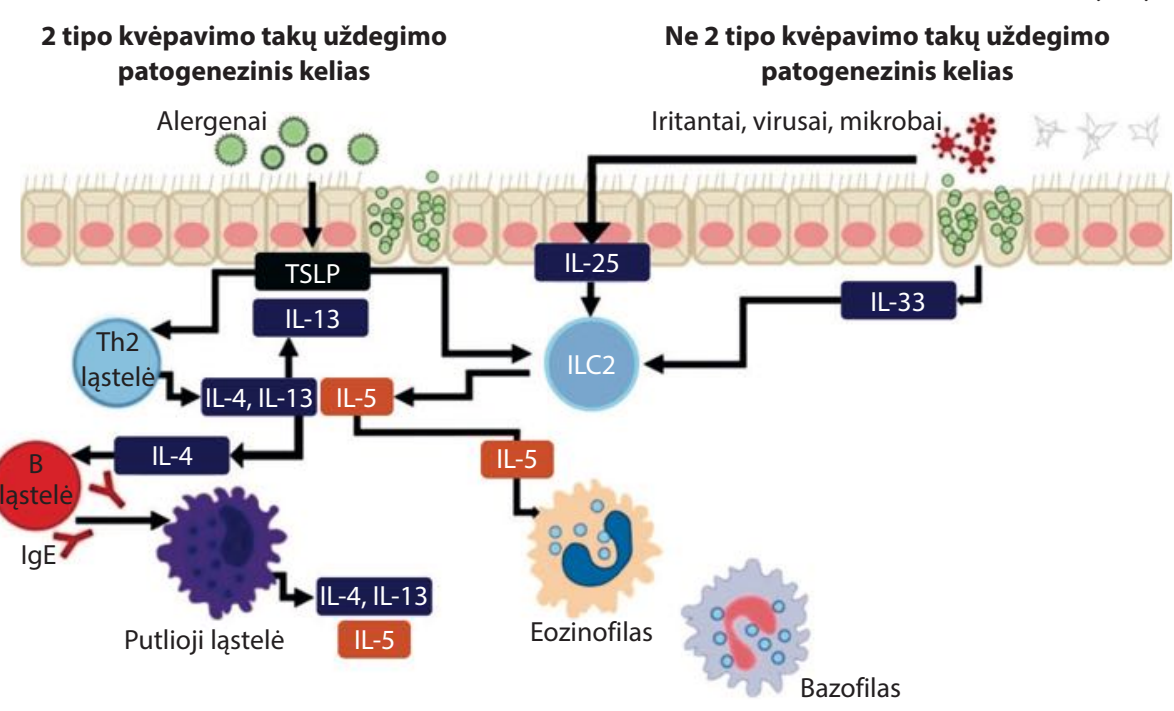

1 pav. 2 tipo ir ne 2 tipo kvèpavimo takų uždegimo patogeneziniai keliai [modifikuota pagal 10]

Ig - imunoglobulinas; IL - interleukinas; ILC2 - igimtos 2 tipo limfoidinès ląstelès; Th2 - 2 tipo T limfocitai pagalbininkai; TSLP - užkrūčio liaukos stromos limfopoetinas. biologinių žymenų svarbą bei naujas prieš 2 tipo kvèpavimo takų uždegimą nukreipto gydymo galimybes.

\section{METODAI}

Apžvalgoje pateikiama informacija, gauta iš laisvai prieinamų mokslinių periodinių leidinių „Clarivate Analytics Web of Science“, „Scopus“ ir "Springerlink“ duomenų bazèse. Informacija buvo surinkta naudojant Nacionalinio biotechnologiju informacijos centro (NCBI) „PubMed“ ir PMC, „Google Scholar“ bei „Wiley Online Library" paieškos sistemas. Informacijai rinkti buvo vartojami šie raktiniai žodžiai: 2 tipo kvėpavimo takų uždegimas, eozinofilai, imunoglobulinas (Ig) E, azoto monoksido frakcija iškvepiamame ore $\left(\mathrm{Fe}_{\mathrm{NO}}\right)$, serumo periostino koncentracija, astma, LOPL.

\section{TIPO KVÉPAVIMO TAKŲ UŽDEGIMO IŠSIVYSTYMO KELIAS}

Kvépavimo takai nuolat kontaktuoja su iritantais, virusais ir mikrobais. Epitelio ląstelès yra pirmasis gynybos barjeras, apsaugantis kvejpavimo takus nuo žalingo aplinkos poveikio. Reaguojant ị šiuos išorinius veiksnius, epitelio ląstelès išskiria daug biologiškai aktyvių medžiagų, kurios svarbios aktyvinant uždegimines ląsteles ir inicijuojant uždegiminị atsaką. Epitelio ląstelių išskiriami citokinai IL-33, IL-25 ir TSLP vadinami aliarminais. Šie aliarminai inicijuoja

\begin{tabular}{|l|c|c|c|c|}
\hline \multicolumn{1}{|c|}{ Endotipai } & \multicolumn{2}{c|}{2 tipo } & \multicolumn{2}{c|}{ Ne 2 tipo } \\
\hline Endotipų potipiai & $\begin{array}{c}\text { Eozino- } \\
\text { filinis }\end{array}$ & $\begin{array}{c}\text { Mišrus gra- } \\
\text { nuliocitinis }\end{array}$ & $\begin{array}{c}\text { Neutro- } \\
\text { filinis }\end{array}$ & $\begin{array}{c}\text { Paucigranu- } \\
\text { liocitinis }\end{array}$ \\
\hline Eozinofilų kiekis skrepliuose & $>3$ proc. & $>3$ proc. & $\leq 3$ proc. & $\leq 3$ proc. \\
\hline Neutrofilų kiekis skrepliuose & $<64$ proc. & $>64$ proc. & $\geq 64$ proc. & $\geq 64$ proc. \\
\hline
\end{tabular}




\section{Moksliniai darbai ir apžvalgos}

tarpląstelinio signalo perdavimą i Th2 ir ILC2, taip skatina IL-4, IL-5 ir IL-13 išskyrimą. Šie citokinai aktyvina eozinofilopoezę ir lemia eozinofiliją $[15,16]$.

2 tipo kvėpavimo takų uždegimas gali vykti dviem skirtingais patogeneziniais keliais - per Th2 arba ILC2 (1 pav.) [10]. Pirmuoju atveju uždegimas vadinamas 2 tipo uždegimu (angl. Th2 high), antruoju atveju - ne 2 tipo uždegimu (angl. Th2 low) [13]. 2 tipo kvejpavimo takų uždegimo metu kvėpavimo takus paveikus alergenui ir iš epitelio ląstelių išsiskyrus aliarminams, dendritinès ląstelès pateikia T limfocitų pagalbininkų žymeni (angl. cluster of differentiation, CD4+) naiviesiems T limfocitams pagalbininkams (angl. naive helper T cells, Th0) ir sužadina jų diferencijaciją i Th2 ląsteles. Šios ląstelès migruoja ị kvèpavimo takų epitelị ir pogleivị, kuriuose išskiria įvairius 2 tipo kvèpavimo takų uždegimo citokinus (daugiausiai IL-4, IL-5, IL-13) [17]. Ne Th2 kvejpavimo takų uždegimo atveju kvėpavimo takus paveikus iritantams, virusams arba mikrobams ir iš epitelio ląstelių išsiskyrus aliarminams, aktyvuojamos ILC2 ląstelès. Šios ląstelès gamina daug 2 tipo kvẻpavimo takų uždegimo citokinų (IL-5 ir IL-13), kurie skatina eozinofilų gamybą, aktyvumą, judejjimą ir palaiko eozinofilinį uždegimą $[11,12]$.

2 tipo kvèpavimo takų uždegimo metu išskiriami citokinai vaidina svarbų vaidmenị vystantis astmai ir LOPL $[3,4]$. IL-4 yra vyraujantis 2 tipo kvėpavimo takų uždegimo citokinas, kuris yra vienas svarbiausių 2 tipo kvėpavimo takų uždegimo patogenezèje [18]. Šis citokinas, kartu su IL-13 skatina plazmines ląsteles gaminti IgE. IgE jungiasi prie putliųjų ląstelių bei bazofilų ir taip sukelia vietines alergines reakcijas [19]. Itin reikšmingas IL-5 vaidmuo, nes jis yra vienas iš pagrindinių citokinų, turinčių poveikị eozinofilams [20]. Irodyta, kad IL-5 yra labai svarbus formuojantis, bręstant ir išgyvenant eozinofilams. IL-5 stimuliuoja eozinofilų gamybą kaulų čiulpuose, taip pat eozinofilų bei bazofilų aktyvumą ir judejjimą. Tokiu būdu palaikomas eozinofilinis kvėpavimo takų uždegimas, kuris ilgainiui sąlygoja struktūrinius kvėpavimo takų pokyčius. Dèl šios priežasties IL-5 pasirenkamas kaip prioritetinis taikinys eozinofilijai mažinti [21].

\section{EOZINOFILU STRUKTŪRA IR JỤ BIOLOGINIS VAIDMUO ESANT 2 TIPO KVĖPAVIMO TAKUุ UŽDEGIMUI}

Vyraujant 2 tipo kvejpavimo takų uždegimui, pagrindinis vaidmuo ligos patogenezejje tenka eozinofilams, kurie taip pat turi poveikį kitoms uždegiminėms ląstelèms [5]. Eozinofilai yra galutinai diferencijavę granulių turintys leukocitai, kurie gaminami kaulų čiulpuose [22]. Sveikiems asmenims eozinofilu susidaro nedaug, todèl ir sisteminëje kraujotakoje jų cirkuliuojantis kiekis nèra didelis [23]. Eozinofilai kraujyje gyvena nuo 16 iki 36 val., migravę i audinius - nuo dviejų iki penkių dienų [24], o veikiant citokinams, jų išgyvenamumas gali prailgèti iki 1-2 savaičių. Migravusios ị audinius, šios ląstelès aktyviai reguliuoja ịvairius imuninius atsakus, išskirdamos biologiškai aktyvias medžiagas [25]. Eozinofiluose paprastai yra apie 200 morfologiškai skirtingų citoplazminių granulių, kuriose yra daug toksiškų baltymų ir kitų mediatorių, kurie sustiprina uždegiminį atsaką ir sukelia audinių pažeidimus [26]. Šiose ląstelèse sintezuojami daugiau kaip 35 rūšiu citokinų, chemokinų ir augimo veiksnių [23]. Eozinofilų išskiriami uždegimą skatinamieji mediatoriai pažeidžia epiteli, skatina kraujagyslių išsiplètimą, lygiưjų raumenų susitraukimą, padidejjusią gleivių sekreciją, o tai yra susiję su kvėpavimo takų hiperreaktyvumu [27]. Irodytas glaudus ryšys tarp eozinofilijos ir plaučiu funkcijos blogejimo, labiau išreikštų simptomų, ligos paūmèjimų tiek eozinofilinès astmos, tiek eozinofilinès LOPL atveju, todèl eozinofilų skaičiaus mažinimas yra 2 tipo kvejpavimo takų uždegimo slopinimo prioritetas $[28,29]$. Eozinofilų proliferaciją, brendimą, aktyvaciją ir išgyvenamumą daugiausia kontroliuoja IL-5, todèl, siekiant mažinti eozinofiliją, IL-5 pasirenkamas kaip gydymo taikinys [27].

\section{TIPO KVĖPAVIMO TAKU UŽDEGIMO BIOLOGINIAI ŽYMENYS}

Geresnis supratimas apie astmos ir LOPL heterogeniškumą bei jų fenotipus ir endotipus, skirtingas šiu ligų atsakas ị skiriamą gydymą paskatino ieškoti biologinių žymenų, kurie padetų nustatyti ligos fenotipą ir (arba) endotipą bei parinkti tinkamiausią gydymą [19]. Tirta daug biologinių žymenų, tačiau tik keletas iš jų naudojami klinikinèje praktikoje [30]. 2 tipo kvejpavimo takų uždegimui priskiriami šie penki biologiniai žymenys: kraujo eozinofilų kiekis, skreplių eozinofilų kiekis, IgE kiekis kraujo serume, $\mathrm{Fe}_{\mathrm{NO}}$ kiekis iškvepiamame ore ir periostino kiekis kraujo serume. Šie biologiniai žymenys ypač svarbūs nustatant ligos fenotipą bei endotipą ir prognozuojant atsaką i gydymą, kuris nukreiptas prieš 2 tipo kvẻpavimo takų uždegimą [12]. Deja, nè vienas iš nurodytų biologinių žymenų nèra patikimas ir visi turi savo trūkumų. Biologinių žymenų kiekis gali kisti priklausomai nuo paros laiko, įtakos tyrimo rezultatams gali turèti paciento svoris, alergenu poveikis, vartojami vaistai, infekcija, rūkymas, be to biologinių žymenų kiekio nustatymui reikia specializuotos įrangos [31]. Dèl šių priežasčių vieno biologinio žymens tyrimas netikslingas [32]. Siekiant padidinti šių tyrimų jautrumą ir specifiškumą bei geriau atpažinti 2 tipo kvẻpavimo takų uždegimą, rekomenduojama tirti ne mažiau dviejų biologinių žymenų. Rekomenduojama nepasikliauti vienkartiniu tyrimo atsakymu, o ji kartoti. Keleto biologinių žymenų derinys ir jų pakartotinis tyrimas gali būti naudingi atrenkant pacientus ir numatant gydymo, nukreipto 


\section{Moksliniai darbai ir apžvalgos}

prieš 2 tipo kvẻpavimo takų uždegimą, veiksmingumą [33]. Biologiniams žymenims keliami reikalavimai, kad jie būtų informatyvūs, lengvai išmatuojami ir nereikalautų daug kaštų [19].

Šiuo metu naudojami 2 tipo kvèpavimo takų uždegimo biologiniai žymenys:

- Kraujo eozinofilų kiekis. Tai daugiausia ištirtas ir plačiausiai klinikinejje praktikoje naudojamas biologinis žymuo [31]. Eozinofilai gaminami kaulų čiulpuose, veikiant IL-3, IL-5 ir granuliocitųmakrofagų kolonijas stimuliuojamajam veiksniui (angl. granulocyte-macrophage colony stimulating factor, GM-CSF) [34]. Eozinofilų kiekio kraujyje nustatymas yra minimaliai invazyvus, lengvai prieinamas, paprastai ir greitai atliekamas tyrimas, kuriam nereikalinga specializuota íranga [31]. Viršutinè eozinofilų normos riba gali skirtis pagal ivvairių laboratorijų vertes. Siekiant nuspèti 2 tipo kvėpavimo takų uždegimą, ribine verte laikomas 150 eozinofilų mikrolitre kiekis [35]. Eozinofilų kiekis kraujyje yra svarbus nustatant ligos endotipą bei fenotipą [36], parenkant individualizuotą gydymą bei prognozuojant atsaką i biologinius vaistus [31].

- Skreplių eozinofiluc kiekis. Eozinofilų kiekio nustatymas skrepliuose reikalauja specializuotos i̇rangos ir patirties turinčių darbuotojų, todèl gali būti atliekamas tik specializuotuose centruose. Be to, šiam tyrimui reikalingi skrepliai, o jų surinkimas kai kuriems pacientams itin sudètingas arba visai negalimas [31]. Eozinofilų kiekis skrepliuose iprastai sudaro $<1,1$ proc. visu ląstelių, o >3 proc. eozinofilų kiekis laikomas kliniškai reikšminga ribine verte, siekiant nuspèti 2 tipo kvẻpavimo takų uždegimą ir parinkti optimaliausią gydymą [37]. Skreplių eozinofilų kiekis taip pat svarbus nustatant ligos endotipą ir parenkant individualizuotą gydymą. Skreplių eozinofilų kiekis priklauso nuo kraujo eozinofilų kiekio [38].

- Bendrojo IgE kiekis kraujo serume. Bendrojo IgE kiekio kraujyje nustatymas yra lengvai prieinamas, minimaliai invazyvus, paprastai ir greitai atliekamas tyrimas, kuriam nereikalinga specializuota ịranga [31]. IgE gamina plazminès ląstelès, veikiant Il-4 ir IL-13 [19]. Šio biologinio žymens kiekis kraujo serume yra svarbus atrenkant alergine astma sergančius pacientus, kuriems galimas prieš IgE nukreiptas gydymas ir sprendžiant dèl anti-IgE antikūno omalizumabo dozès bei vaisto skyrimo dažnio. Omalizumabas skiriamas pacientams, kurių IgE kiekis kraujo serume svyruoja 30-1500 IU/l ribose. Esant didesniam IgE kiekiui, omalizumabas neskiriamas, nes nepakanka duomenų dèl rekomenduotinos šio vaisto dozès [31].
- $\mathbf{F e}_{\mathrm{NO}}$ kiekis iškvepiamame ore. $\mathrm{Fe}_{\mathrm{NO}}$ kiekio nustatymas iškvepiamame ore yra neinvazinis, greitai atliekamas ir nedaug paciento pastangų reikalaujantis tyrimas, rodantis 2 tipo kvejpavimo taku uždegimą [31]. Azoto monoksidą (NO) gamina kvépavimo takų epitelio ląstelès, eozinofilai ir makrofagai fermentui azoto oksido sintazei aminorūgštị L-argininą paverčiant ị L-citruliną [5]. Ribine verte, siekiant nustatyti 2 tipo kvejpavimo takų uždegimą, laikomas 25 ppb $\mathrm{Fe}_{\mathrm{NO}}$ kiekis [31]. Šio biologinio žymens kiekis didejja proporcingai intensyvejjant 2 tipo kvejpavimo takų uždegimui, todèl $\mathrm{Fe}_{\mathrm{NO}}$ matavimas naudingas ne tik nustatant 2 tipo kvẻpavimo takų uždegimą ir vertinant jo intensyvumą, bet ir numatant ligos eigą bei biologinių vaistų veiksmingumą, slopinant 2 tipo kvėpavimo takų uždegimą $[12,39]$. Nors $\mathrm{Fe}_{\mathrm{NO}}$ kiekị didina rūkymas, kvėpavimo takų infekcija, fizinè veikla, o panaudojimą riboja įrangos ir paties tyrimo kaina, ši tyrimą vertètų dažniau ịtraukti ị kasdienę klinikinę praktiką [31].

- Periostino kiekis kraujo serume. Periostino kiekio kraujyje nustatymas yra minimaliai invazyvus ir greitai atliekamas tyrimas. Šis biologinis žymuo gaminamas fibroblastų, epitelio ir endotelio ląstelių, veikiant IL-4 ir IL-13 [40, 41]. Periostino kiekis kraujyje priklauso nuo amžiaus: vaikams yra didesnis nei suaugusiesiems ir viršija $50 \mathrm{ng} / \mathrm{l}$, o esant intensyviam vaiko augimui (nuo gimimo iki dvejų metų ir nuo 11 iki 15 metų), viršija 100 ng/ml. Periostino kieki mažina rūkymas, o didina gretutinès ligos, kaip, atopinis dermatitas, lètinis rinosinusitas, alerginis konjuktyvitas [42]. Dèl šių trūkumų periostino naudojimas klinikinèje praktikoje ribotas, o dažniau tiriamas atliekant mokslinius tyrimus [43].

Vykdomi klinikiniai tyrimai, ieškant naujų biologinių žymenų, kurie būtų svarbūs 2 tipo kvėpavimo takų uždegimo patogenezèje [5]. Manoma, kad daugelis biologiškai aktyvių medžiagų, kurios dalyvauja astmos ir LOPL patogenezèje, galètų būti biologiniais žymenimis [44]. Vienos svarbiausių biologiškai aktyvių medžiagų, dalyvaujančių kvèpavimo takų uždegime, yra citokinai, kurių priskaičiuojama apie 50 [45]. Esant 2 tipo kvėpavimo takų uždegimui, ypač svarbūs Th2 ir ILCS ląstelių gausiai išskiriami citokinai: IL-4, IL-5 ir IL-13 bei epitelio gaminami citokinai: IL-25, IL-33, TSLP. Šių citokinų kiekio kraujo serume nustatymas gali nuspèti 2 tipo kvẻpavimo takų uždegimą, tačiau kol kas minėti citokinai naudojami tik atliekant mokslinius tyrimus ir nèra paplitę klinikineje praktikoje [46]. Paminètinas ir kraujo serumo eotaksinų CCL11 ir CCL17 vaidmuo 2 tipo uždegimo patogenezèje, nes jie didina eozinofilų chemotaksị ir skatina jų telkimąsi plaučiuose. Pastebéta, kad šių eotaksinų koncentracija kraujyje padidèja, 


\section{Moksliniai darbai ir apžvalgos}

sergant uždegiminėmis kvėpavimo takų ligomis, o kartu su kitais 2 tipo kvėpavimo takų uždegimo biologiniais žymenimis gali būti informatyvūs sprendžiant apie 2 tipo kvẻpavimo takų uždegimo intensyvumą [47]. Atlikti tyrimai parodè eozinofilų granulèse esančių biologiškai aktyvių baltymų: eozinofilų katijoninio baltymo (angl. eosinophil cationic protein, ECP), eozinofilų peroksidazès (angl. eosinophil peroxidase, EPO), eozinofilų baltymo X (angl. eosinophil protein X, EPX) ir iš eozinofilų kilusio neurotoksino (angl. eosinophil derived neurotoxin, EDN) naudingumą nustatant 2 tipo kvėpavimo takų uždegimą. Pagal šių baltymų kieki galima nuspèti ligos sunkumą, nes didejjant šių baltymų kiekiui, didèja uždegimo intensyvumas [48]. Apibendrinus galima teigti, kad šiuo metu vykdoma naujų biologinių žymenų paieška. Tikimasi surasti tokị biologinị žymenị, kurio ištyrimas būtų paprastas, pigus, o rezultatai kuo tiksliau leistų nuspèti 2 tipo kvẻpavimo takų uždegimą ir jo intensyvumą.

\section{TIPO KVĖPAVIMO TAKỤ UŽDEGIMO SLOPINIMAS}

Nuo seno astmos ir LOPL gydymo tikslas buvo kvèpavimo takų uždegimo slopinimas [49]. Šio uždegimo mažinimui vartojami ikkvepiamieji gliukokortikoidai (IGK). Nepaisant jų skyrimo kartu su bronchus plečiamaisiais vaistais, daliai pacientų nepavyksta pasiekti pakankamo gydymo veiksmingumo ir išvengti ligos paūmèjimų. Ligai paūmẻjus, dažnai tenka vartoti sisteminius gliukokortikoidus, kurie sukelia nepageidaujamus vaisto poveikius. Dèl šios priežasties pradèta ieškoti naujų gydymo galimybių [13].

Supratimas apie astmos ir LOPL patogenezę pradèjo keistis prieš du dešimtmečius. Tuo metu atsirado daugiau žinių apie 2 tipo kvejpavimo takų uždegimą bei biologinius žymenis, kurie gali padèti šį uždegimą atpažinti. Visa tai paskatino domètis gydymo galimybemis, atlikti klinikinius tyrimus su monokloniniais antikūnais, nukreiptais prieš 2 tipo kvejpavimo takų uždegimo citokinus ir juc receptorius [50]. Šiuo metu klinikinèje praktikoje 2 tipo kvẻpavimo takų uždegimo slopinimui patvirtinti ir tiriami biologiniai vaistai pateikiami 2 pav. [51].

$2003 \mathrm{~m}$. patvirtintas prieš IgE nukreiptas monokloninis antikūnas omalizumabas sunkiai pagal 51] liaukos stromos limfopoetinas. alerginei astmai gydyti. Klinikiniai tyrimai ịrodè klinikinį omalizumabo veiksmingumą mažinant astmos simptomus ir IGK poreiki, gerinant plaučių funkciją, retinant ligos paūmejjimus ir vizitus dèl astmos ị gydymo įstaigas, gerinant astmos kontrolę ir gyvenimo kokybę [52].

Prieš du dešimtmečius vykdytų klinikinių tyrimų su mepolizumabu rezultatai nuvylè. Mepolizumabas sumažino eozinofilų kieki kraujyje, tačiau neturejjo teigiamo klinikinio poveikio retinant ligos paūmejjimus. Manoma, kad taip atsitiko dèl astmos heterogeniškumo ir tiriamųjų populiacijos, nes pacientai nebuvo atrinkti pagal ligos sunkumą ir eozinofilų kiekį kraujyje ir (arba) skrepliuose [53]. Vèliau pradèta vykdyti tiriamujuc atranka. Pasirinkti pacientai, kuriems nepaisant skiriamo gydymo didelèmis IGK dozėmis, per metus diagnozuoti mažiausiai du ligos paūmèjimai ir kurių eozinofilų kiekis kraujyje $\geq 300$ eozinofilų mikrolitre ir (arba) skreplių eozinofilų skaičius $\geq 3$ proc. Šiuose klinikiniuose tyrimuose irodytas mepolizumabo veiksmingumas retinant astmos paūmèjimus, mažinant sisteminių gliukokortikoidų vartojimą ir gerinant gyvenimo kokybę [54-59].

Pirmieji klinikiniai tyrimai su reslizumabu taip pat nebuvo sèkmingi. Reslizumabas sumažino eozinofilų kiekị kraujyje ir (arba) skrepliuose, tačiau neturèjo teigiamo klinikinio veiksmingumo retinant ligos paūmejjimus. Tik véliau atkreiptas dèmesys ị tiriamujų populiaciją, t. y. pacientus, atrinkus pagal ligos sunkumą ir eozinofilų kiekị kraujyje ir (arba) skrepliuose, III fazès

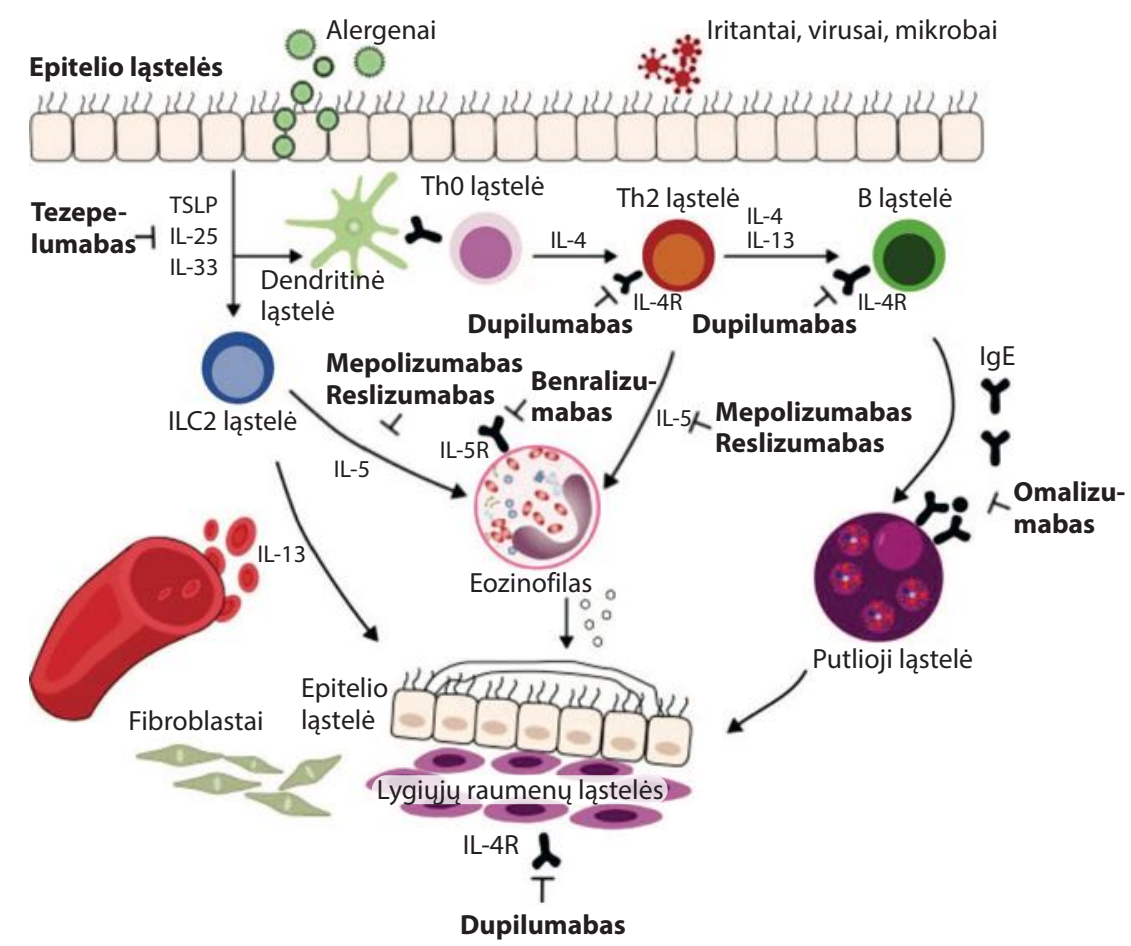

2 pav. 2 tipo kvèpavimo takų uždegimo slopinimas biologiniais vaistais [modifikuota

IL - interleukinas; IL-4R - interleukino 4 receptorius; IL-5R - interleukino 5 receptorius; TSLP - užkrūčio 


\section{Moksliniai darbai ir apžvalgos}

klinikiniuose tyrimuose įrodytas reslizumabo klinikinis veiksmingumas retinant astmos paūmejjimus [60]. Šis vaistas Lietuvoje klinikinejje praktikoje nèra taikomas.

III fazès klinikiniuose benralizumabo veiksmingumo tyrimuose dalyvavo sunkia eozinofiline astma sergantys pacientai. Rezultatai įrodè benralizumabo veiksmingumą retinant ligos paūmèjimus ir mažinant sisteminių gliukokortikoidų vartojimą [61-65].

Atliekant III fazès klinikinius tyrimus su dupilumabu, nustatytas reikšmingas sunkių astmos paūmėjimų retejimas. Didesnis dupilumabo poveikis, retinant astmos paūmejjimus, nustatytas tiriamiesiems, kuriems pradinio vertinimo metu rastas didesnis kraujo eozinofilų, IgE ir $\mathrm{Fe}_{\mathrm{NO}}$ kiekis. Klinikinių tyrimų metu nustatyta, kad, skiriant dupilumabą, reikšmingai pagerèja plaučių funkcija ir gyvenimo kokybė [66-68]. Ivertinus atliktus klinikinius tyrimus, įrodytas dupilumabo klinikinis veiksmingumas gerinant plaučių funkciją, retinant astmos paūmejjimus sergantiesiems astma su 2 tipo kvejpavimo takų uždegimu, kuriems liga nepakankamai kontroliuojama, nepaisant gydymo didelėmis IGK dozėmis su kitu kontroliuojamuoju vaistu [69]. Šis vaistas Lietuvoje klinikinèje praktikoje nèra taikomas sergantiesiems astma.

Tezepelumabas - biologinis vaistas, kuris Europos vaistų agentūros nèra patvirtintas taikyti klinikinèje

2 lentelè. Biologinių vaistų sunkiai astmai gydyti charakteristikų santrauka

\begin{tabular}{|c|c|c|c|c|}
\hline $\begin{array}{l}\text { Biologinis } \\
\text { vaistas }\end{array}$ & Veikimo mechanizmas & $\begin{array}{l}\text { Europos vaistų } \\
\text { agentūros } \\
\text { registracijos } \\
\text { data }\end{array}$ & $\begin{array}{l}\text { Terapinès indikacijos (patvirtintos } \\
\text { Europos vaistų agentūros) }\end{array}$ & $\begin{array}{l}\text { Dozavimas ir vartojimo } \\
\text { būdas, laikymo sąlygos }\end{array}$ \\
\hline $\begin{array}{l}\text { Omalizu- } \\
\text { mabas }\end{array}$ & $\begin{array}{l}\text { Jungiasi su kraujyje cirku- } \\
\text { liuojančiu lgE ir neleidžia jam } \\
\text { jungtis su didelio afiniteto lgE } \\
\text { receptoriumi, todèl sumažèja } \\
\text { laisvojo lgE kiekis }\end{array}$ & $2005 \mathrm{~m}$. & $\begin{array}{l}\text { Kaip papildomas gydymas šešerių metų ir } \\
\text { vyresniems pacientams, sergantiems sunkia } \\
\text { nuolatine alergine astma, kurių odos dūrio } \\
\text { mėginys yra teigiamas arba kuriems in vitro } \\
\text { padidèjęs jautrumas ịkvepiamiesiems alerge- } \\
\text { nams, kurių plaučių funkcija yra pablogejjusi } \\
\left(\text { FEV }_{1}<80 \text { proc. normos)*, kuriems dažnai kar- }\right. \\
\text { tojasi simptomai dieną arba pažadina nakti, } \\
\text { kuriems dokumentuota daug sunkių astmos } \\
\text { paūmèjimų, nepaisant kasdien vartojamų } \\
\text { didelių IGK ir IVBA dozių }\end{array}$ & $\begin{array}{l}\text { Omalizumabo dozė apskai- } \\
\text { čiuojama pagal paciento } \\
\text { kūno svori (kg), lgE kieki } \\
\text { kraujyje ir gali svyruoti nuo } \\
75 \text { iki } 600 \text { mg } \\
\text { Skiriamas kas 2-4 savaites } \\
\text { Leidžiamas i žastų, šlaunų } \\
\text { arba pilvo poodę }\end{array}$ \\
\hline $\begin{array}{l}\text { Mepolizu- } \\
\text { mabas }\end{array}$ & $\begin{array}{l}\text { Jungiasi su IL-5 ir neleidžia } \\
\text { jam jungtis prie IL-5 recep- } \\
\text { toriaus a subvieneto, todèl } \\
\text { slopinamas IL-5 biologinis } \\
\text { aktyvumas }\end{array}$ & $2015 \mathrm{~m}$. & $\begin{array}{l}\text { Kaip papildomas gydymas šešerių metų ir } \\
\text { vyresniems pacientams, sergantiems sunkia } \\
\text { gydymui atsparia eozinofiline astma }\end{array}$ & $\begin{array}{l}12 \text { metų ir vyresniems } \\
\text { pacientams skiriama dozė } \\
100 \text { mg, 6-11 metų - } 40 \text { mg } \\
\text { Skiriamas kas keturias } \\
\text { savaites } \\
\text { Leidžiamas i žastų, šlaunų } \\
\text { arba pilvo poodę }\end{array}$ \\
\hline $\begin{array}{l}\text { Reslizuma- } \\
\text { bas }\end{array}$ & $\begin{array}{l}\text { Jungiasi su IL-5 ir neleidžia } \\
\text { jam jungtis prie IL-5 recep- } \\
\text { toriaus a subvieneto, todèl } \\
\text { slopinamas IL-5 biologinis } \\
\text { aktyvumas }\end{array}$ & $2016 \mathrm{~m}$. & $\begin{array}{l}\text { Kaip papildomas gydymas suaugusiems } \\
\text { pacientams, sergantiems sunkia eozinofiline } \\
\text { astma, kuriems liga nepakankamai kontro- } \\
\text { liuojama, nepaisant gydymo didelèmis IGK } \\
\text { dozėmis su kitu kontroliuojamuoju vaistu }\end{array}$ & $\begin{array}{l}\text { Reslizumabo dozè apskai- } \\
\text { čiuojama pagal kūno svorị } \\
(3 \mathrm{mg} / \mathrm{kg}) \\
\text { Skiriamas kas keturias } \\
\text { savaites } \\
\text { Leidžiamas i veną }\end{array}$ \\
\hline $\begin{array}{l}\text { Benralizu- } \\
\text { mabas }\end{array}$ & $\begin{array}{l}\text { Jungiasi prie IL-5R a subvie- } \\
\text { neto ir neleidžia IL-5 jungtis } \\
\text { prie IL-5R, todèl slopinamas } \\
\text { IL-5 biologinis aktyvumas. } \\
\text { Taip pat jungiasi prie FcyRIII } \\
\text { receptorių, esančiu ant natū- } \\
\text { raliuju žudikių (angl. Natural } \\
\text { killer, NK), todèl sukeliama eo- } \\
\text { zinofilų ir bazofilų apoptozè }\end{array}$ & $2018 \mathrm{~m}$ & $\begin{array}{l}\text { Kaip papildomas palaikomasis gydymas suau- } \\
\text { gusiems pacientams, sergantiems sunkia eo- } \\
\text { zinofiline astma, kuriems liga nepakankamai } \\
\text { kontroliuojama, nepaisant gydymo didelemis } \\
\text { IGK dozemis kartu su IVBA }\end{array}$ & $\begin{array}{l}\text { Skiriama dozè } 30 \mathrm{mg} \\
\text { Pirmos trys dozės skiriamos } \\
\text { kas keturias savaites, vėliau - } \\
\text { kas aštuonias savaites } \\
\text { Leidžiamas i žastų, šlaunų } \\
\text { arba pilvo poodę }\end{array}$ \\
\hline $\begin{array}{l}\text { Dupiluma- } \\
\text { bas }\end{array}$ & $\begin{array}{l}\text { Jungiasi prie } 1 \text { tipo IL-4R a } \\
\text { subvieneto ir prie } 2 \text { tipo IL-4R } \\
\text { ir IL-13R a subvienetu, todèl } \\
\text { slopinamas IL-4 ir IL-13 bio- } \\
\text { loginis aktyvumas }\end{array}$ & $2019 \mathrm{~m}$. & $\begin{array}{l}\text { Kaip papildomas palaikomasis gydymas } 12 \\
\text { metų ir vyresniems pacientams, sergantiems } \\
\text { sunkia astma su } 2 \text { tipo kvėpavimo takų užde- } \\
\text { gimu, kuriam būdingas padidėjęs eozinofilu } \\
\text { kiekis kraujyje ir (arba) padidėjęs Fe }{ }_{\text {No }} \text { kiekis, } \\
\text { kuriems liga nepakankamai kontroliuojama, } \\
\text { nepaisant gydymo didelemis IGK dozėmis su } \\
\text { kitu kontroliuojamuoju vaistu }\end{array}$ & $\begin{array}{l}\text { Pradinè skiriama dozè } 400- \\
600 \text { mg, vèliau } 200-300 \text { mg } \\
\text { Skiriamas kas dvi savaites } \\
\text { Leidžiamas i žastų, šlaunų } \\
\text { arba pilvo poodę }\end{array}$ \\
\hline
\end{tabular}

FeNO - azoto monoksidas iškvepiamame ore; Ig - imunoglobulinas; IGK - įkvepiamieji gliukokortikoidai; IVBA - ilgo veikimo $\beta_{2}$ agonistai; IL - interleukinas; IL-4R - interleukino 4 receptorius; IL-5R - interleukino 5 receptorius; IL-13R - interleukino 13 receptorius. ${ }^{*}$ kriterijus neprivalomas $6-11$ metų amžiaus pacientams 


\section{Moksliniai darbai ir apžvalgos}

praktikoje. Preliminarūs IIB fazes klinikinių tyrimų rezultatai rodo tezepelumabo veiksmingumą mažinant ligos simptomus, gerinant plaučiu funkciją, retinant ligos paūmèjimus, prailginant laiką iki pirmo ligos paūmejjimo ir gerinant gyvenimo kokybę sergantiesiems astma. Vykdomi II ir III fazès klinikiniai tyrimai siekiant įvertinti tezepelumabo veiksmingumą ir saugumą [70]. Kadangi tezepelumabas jungiasi prie aliarmino TSLP, blokuojamas ir 2 tipo, ir ne 2 tipo uždegimas, o tai lemia platesni tezepelumabo terapini poveikị, lyginant su anksčiau minètais prieš citokinus ir jų receptorius nukreiptais biologiniais vaistais [71].

Europos vaistų agentūros patvirtinti biologiniai vaistai sunkiai astmai gydyti pateikiami 2 lenteleje [72].

Naujai sukurti biologiniai vaistai sergantiesiems astma padeda pasiekti ligos kontrolę, retina ligos paūmëjimus, padeda išvengti nepageidaujamo sisteminiu gliukokortikoidų poveikio, kuriuos neretai tenka vartoti ligai paūmèjus [13]. Dẻl šių priežasčių biologinių vaistų sukūrimas prilyginamas sunkios astmos gydymo perversmui $[73,74]$.

Kalbant apie LOPL, daliai sergančiųjų šiuo metu skiriamas standartinis gydymas nèra pakankamai veiksmingas mažinant ligos simptomus, gerinant plaučių funkciją ir retinant ligos paūmèjimus. Nepaisant skiriamos trigubos terapijos, trečdaliui pacientų nepasiekiama LOPL kontrolè [75]. Dèl šios priežasties siekiama biologinius vaistus pritaikyti ir sergantiesiems LOPL. Tikimasi, kad pacientams, kuriems būdingas 2 tipo kvèpavimo takų uždegimas, šie vaistai gali būti veiksmingi gydant LOPL kaip ir gydant astmą [76].

Pirmasis biologinis vaistas, kurio poveikis tirtas sergantiesiems LOPL, buvo mepolizumabas. Atlikus 2 III fazès mepolizumabo klinikinius tyrimus, kurių pirminè vertinamoji baigtis vidutinio sunkumo ir sunkiu LOPL paūmėjimų dažnis per metus, pastebèta, kad šis biologinis vaistas $18-20$ proc. suretina LOPL paūmèjimus. Vertinant antrines vertinamąsias baigtis, tai yra laiką iki pirmo vidutinio sunkumo arba sunkaus LOPL paūméjimo, vieno iš klinikinių tyrimų rezultatai ịrodè mepolizumabo klinikinį veiksmingumą prailginant ši laiką, o kito - rezultatai buvo kliniškai nereikšmingi. Vertinant kitas vertinamąsias baigtis - tai paūmèjimų, kai pacientui reikia gydymo Skubiosios pagalbos skyriuje arba stacionare, dažnị ir sergančiųų LOPL gyvenimo kokybę, kliniškai reikšmingų skirtumų vartojant mepolizumabą ir lyginant su placebu nebuvo [75]. Šiuo metu vykdomi dar 2 III fazès klinikiniai tyrimai, kurių pabaiga numatoma $2023 \mathrm{~m}$.

Tuo tarpu atlikus 2 III fazès klinikinius tyrimus su benralizumabu, kurių pirminè vertinamoji baigtis buvo vidutinio sunkumo ir sunkių LOPL paūmèjimų dažnis per vienerius metus ir LOPL paūmèjimų retinimas, benralizumabo veiksmingumas nebuvo kliniškai reikš- mingas. Vertinant antrines vertinamąsias baigtis - tai plaučių funkciją prieš bronchus plečiamuosius vaistus ir gyvenimo kokybę, benralizumabo veiksmingumas taip pat nebuvo kliniškai reikšmingas. Atsižvelgiant šias pirmines ir antrines vertinamąsiais baigtis bei jų rezultatus, tolesnè kitų vertinamųjų baigčių rezultatų analizè nebuvo skelbiama, nes negalèjo būti laikoma statistiškai reikšminga [77]. Šiuo metu analizuojamos galimos šių klinikinių tyrimų nesėkmės priežastys. Manoma, kad tai galèjo nutikti dèl ne visiškai tinkamai atrinktos tiriamuju populiacijos.

Dupilumabas taip pat tiriamas kaip galimas biologinis vaistas sergantiesiems LOPL. Šiuo metu atliekamas III fazès klinikinis tyrimas, kurio tikslas - ịvertinti dupilumabo veiksmingumą, saugumą ir toleravimą sergantiesiems vidutinio sunkumo arba sunkia LOPL ir esant $\geq 300$ eozinofilų kraujo mikrolitre. Dar tęsiamas pacientų itraukimas, o numatoma tyrimo pabaiga $2023 \mathrm{~m}$. [78].

Klinikinis tyrimas šiuo metu atliekamas ir su tezepelumabu. IIA fazès tyrimo tikslas -ịvertinti tezepelumabo veiksmingumą ir saugumą gydant sergančiuosius vidutinio sunkumo arba sunkia LOPL. Numatoma tyrimo pabaiga $2023 \mathrm{~m}$. [79].

\section{IŠVADOS}

Astmos ir LOPL patogenezeje svarbus vaidmuo tenka 2 tipo kvėpavimo takų uždegimui. Pagerèjęs supratimas apie šio uždegimo išsivystymą, biologinių žymenų ịdiegimas ị klinikinę praktiką ir sékmingas biologinių vaistų taikymas sukèle perversmą gydant astmą ir atvėré kelią tolesniems LOPL tyrimams.

Gauta 20210806

Priimta 20210826

\section{LITERATŪRA}

1. Kaplan A, van Boven JFM, Ryan D, Tsiligianni I, BosnicAnticevich S, Group REGAW. GINA 2020: Potential impacts, opportunities, and challenges for primary care. J Allergy Clin Immunol Pract. 2021; 9(4):1516-9.

2. Halpin DMG, Criner GJ, Papi A, Singh D, Anzueto A, Martinez FJ, et al. Global initiative for the diagnosis, management, and prevention of chronic obstructive lung disease. The 2020 GOLD science committee report on COVID-19 and chronic obstructive pulmonary disease. Am J Respir Crit Care Med. 2021; 203(1):24-36.

3. Dunican EM, Fahy JV. The role of type 2 inflammation in the pathogenesis of asthma exacerbations. Ann Am Thorac Soc. 2015; 12 Suppl 2:S144-9.

4. Brightling C, Greening N. Airway inflammation in COPD: progress to precision medicine. Eur Respir J. 2019; 54(2).

5. Kuruvilla ME, Lee FE, Lee GB. Understanding asthma phenotypes, endotypes, and mechanisms of disease. Clin Rev Allergy Immunol. 2019; 56(2):219-33.

6. Wang Y, Xu J, Meng Y, Adcock IM, Yao X. Role of inflammatory cells in airway remodeling in COPD. Int J Chron Obstruct Pulmon Dis. 2018; 13:3341-8.

7. Fehrenbach H, Wagner C, Wegmann M. Airway remodeling in asthma: what really matters. Cell Tissue Res. 2017; 367(3):551-69.

8. Aghasafari P, George U, Pidaparti R. A review of inflammatory mechanism in airway diseases. Inflamm Res. 2019; 68(1):59-74.

9. Tliba O, Panettieri RA, Jr. Paucigranulocytic asthma: uncou- 


\section{Moksliniai darbai ir apžvalgos}

pling of airway obstruction from inflammation. J Allergy Clin Immunol. 2019; 143(4):1287-94

10. David B, Bafadhel M, Koenderman L, De Soyza A. Eosinophilic inflammation in COPD: from an inflammatory marker to a treatable trait. Thorax. 2021; 76(2):188-95.

11. Henry EK, Inclan-Rico JM, Siracusa MC. Type 2 cytokine responses: regulating immunity to helminth parasites and allergic inflammation. Curr Pharmacol Rep. 2017; 3(6):346-59.

12. Robinson $D$, Humbert $M, B$ Bhl $R$, Cruz AA, Inoue $H$ Korom S, et al. Revisiting type 2-high and type 2-low airway inflammation in asthma: current knowledge and therapeutic implications. Clin Exp Allergy. 2017; 47(2):161-75.

13. Fahy JV. Type 2 inflammation in asthma--present in most, absent in many. Nat Rev Immunol. 2015; 15(1):57-65.

14. Pavord ID, Corren J. Biomarkers of type 2 airway inflammation in airway disease: and then there were two. J Allergy Clin Immunol Pract. 2020; 8(8):2640-2.

15. Hong H, Liao S, Chen F, Yang Q, Wang DY. Role of IL-25, IL33 , and TSLP in triggering united airway diseases toward type 2 inflammation. Allergy. 2020; 75(11):2794-804.

16. Porsbjerg CM, Sverrild A, Lloyd CM, Menzies-Gow AN, Bel EH. Anti-alarmins in asthma: targeting the airway epithelium with next-generation biologics. Eur Respir J. 2020; 56(5).

17. Gandhi NA, Bennett BL, Graham NM, Pirozzi G, Stahl N, Yancopoulos GD. Targeting key proximal drivers of type 2 inflammation in disease. Nat Rev Drug Discov. 2016; 15(1):35-50.

18. KleinJan A. Airway inflammation in asthma: key players beyond the Th2 pathway. Curr Opin Pulm Med. 2016; 22(1):46-52.

19. Bhakta NR, Woodruff PG. Human asthma phenotypes: from the clinic, to cytokines, and back again. Immunol Rev. 2011; 242(1):220-32.

20. Zhu J. T helper 2 (Th2) cell differentiation, type 2 innate lymphoid cell (ILC2) development and regulation of interleukin-4 (IL-4) and IL-13 production. Cytokine. 2015; 75(1):14-24.

21. Cai T, Qiu J, Ji Y, Li W, Ding Z, Suo C, et al. IL-17-producing ST2(+) group 2 innate lymphoid cells play a pathogenic role in lung inflammation. J Allergy Clin Immunol. 2019; 143(1):22944 e9.

22. Weller PF, Spencer LA. Functions of tissue-resident eosinophils. Nat Rev Immunol. 2017; 17(12):746-60.

23. Davoine F, Lacy P. Eosinophil cytokines, chemokines, and growth factors: emerging roles in immunity. Front Immunol. 2014; 5:570.

24. Park YM, Bochner BS. Eosinophil survival and apoptosis in health and disease. Allergy Asthma Immunol Res. 2010; 2(2):87-101

25. O'Sullivan JA, Bochner BS. Eosinophils and eosinophilassociated diseases: An update. J Allergy Clin Immunol. 2018; 141(2):505-17

26. Ueki S, Tokunaga T, Fujieda S, Honda K, Hirokawa $M$, Spencer LA, et al. Eosinophil etosis and dna traps: a new look at eosinophilic inflammation. Curr Allergy Asthma Rep. 2016; 16(8):54.

27. Farne HA, Wilson A, Powell C, Bax L, Milan SJ. Anti-IL5 therapies for asthma. Cochrane Database Syst Rev. 2017; 9:CD010834.

28. Bystrom J, Amin K, Bishop-Bailey D. Analysing the eosinophil cationic protein--a clue to the function of the eosinophil granulocyte. Respir Res. 2011; 12:10.

29. Narendra DK, Hanania NA. Targeting IL-5 in COPD. Int J Chron Obstruct Pulmon Dis. 2019; 14:1045-51.

30. Kunc P, Fabry J, Lucanska M, Pecova R. Biomarkers of bronchial asthma. Physiol Res. 2020; 69(Suppl 1):S29-S34.

31. Narendra D, Blixt J, Hanania NA. Immunological biomarkers in severe asthma. Semin Immunol. 2019; 46:101332.

32. Nixon J, Newbold P, Mustelin T, Anderson GP, Kolbeck R. Monoclonal antibody therapy for the treatment of asthma and chronic obstructive pulmonary disease with eosinophilic inflammation. Pharmacol Ther. 2017; 169:57-77.

33. Coumou H, Bel EH. Improving the diagnosis of eosinophilic asthma. Expert Rev Respir Med. 2016; 10(10):1093-103.

34. Simon HU, Yousefi S, Germic N, Arnold IC, Haczku A, Karaulov AV, et al. The cellular functions of eosinophils: Collegium Internationale Allergologicum (CIA) Update 2020. Int Arch Allergy Immunol. 2020; 181(1):11-23.

35. Brusselle G, Pavord ID, Landis S, Pascoe S, Lettis S, Morjaria
$\mathbf{N}$, et al. Blood eosinophil levels as a biomarker in COPD. Respir Med. 2018; 138:21-31.

36. Nagase H, Ueki S, Fujieda S. The roles of IL-5 and anti-IL-5 treatment in eosinophilic diseases: asthma, eosinophilic granulomatosis with polyangiitis, and eosinophilic chronic rhinosinusitis. Allergol Int. 2020; 69(2):178-86.

37. Svenningsen S, Nair P. Asthma endotypes and an overview of targeted therapy for asthma. Front Med (Lausanne). 2017; 4:158.

38. Barnes PJ. Inflammatory mechanisms in patients with chronic obstructive pulmonary disease. J Allergy Clin Immunol. 2016; 138(1):16-27.

39. Badar A, Salem AM, Bamosa AO, Qutub HO, Gupta RK, Siddiqui IA. Association between FeNO, total blood IgE, peripheral blood eosinophil and inflammatory cytokines in partly controlled asthma. J Asthma Allergy. 2020; 13:533-43.

40. Li W, Gao P, Zhi Y, Xu W, Wu Y, Yin J, et al. Periostin: its role in asthma and its potential as a diagnostic or therapeutic target. Respir Res. 2015;16:57.

41. Izuhara K, Nunomura S, Nanri Y, Ogawa M, Ono J, Mitamura Y, et al. Periostin in inflammation and allergy. Cell Mol Life Sci. 2017; 74(23):4293-303

42. Izuhara K, Nunomura S, Nanri Y, Ono J, Takai M, Kawaguchi A. Periostin: an emerging biomarker for allergic diseases. Allergy. 2019; 74(11):2116-28.

43. Takahashi K, Meguro K, Kawashima H, Kashiwakuma D, Kagami SI, Ohta S, et al. Serum periostin levels serve as a biomarker for both eosinophilic airway inflammation and fixed airflow limitation in well-controlled asthmatics. J Asthma. 2019; 56(3):236-43

44. Caminati M, Pham DL, Bagnasco D, Canonica GW. Type 2 immunity in asthma. World Allergy Organ J. 2018; 11(1):13.

45. Walsh GM. Targeting eosinophils in asthma: current and future state of cytokine- and chemokine-directed monoclonal therapy. Expert Rev Clin Immunol. 2010; 6(5):701-4.

46. Zissler UM, Esser-von Bieren J, Jakwerth CA, Chaker AM, Schmidt-Weber CB. Current and future biomarkers in allergic asthma. Allergy. 2016; 71(4):475-94.

47. Machura E, Rusek-Zychma M, Jachimowicz M, Wrzask M, Mazur B, Kasperska-Zajac A. Serum TARC and CTACK concentrations in children with atopic dermatitis, allergic asthma, and urticaria. Pediatr Allergy Immunol. 2012; 23(3):278-84.

48. Venge P. Monitoring the allergic inflammation. Allergy. 2004; 59(1):26-32.

49. Wechsler ME. Current and emerging biologic therapies for asthma and COPD. Respir Care. 2018; 63(6):699-707.

50. O'Dwyer DN, Moore BB. The role of periostin in lung fibrosis and airway remodeling. Cell Mol Life Sci. 2017; 74(23):430514.

51. Krings JG, McGregor MC, Bacharier LB, Castro M. Biologics for severe asthma: treatment-specific effects are important in choosing a specific agent. J Allergy Clin Immunol Pract. 2019; 7(5):1379-92.

52. Pelaia C, Calabrese C, Terracciano R, de Blasio F, Vatrella A, Pelaia G. Omalizumab, the first available antibody for biological treatment of severe asthma: more than a decade of real-life effectiveness. Ther Adv Respir Dis. 2018; 12:1753466618810192.

53. Flood-Page $P$, Swenson $C$, Faiferman $I$, Matthews J, Williams M, Brannick L, et al. A study to evaluate safety and efficacy of mepolizumab in patients with moderate persistent asthma. Am J Respir Crit Care Med. 2007; 176(11):1062-71.

54. Edris A, De Feyter S, Maes T, Joos G, Lahousse L. Monoclonal antibodies in type 2 asthma: a systematic review and network meta-analysis. Respir Res. 2019; 20(1):179.

55. Pavord ID, Korn S, Howarth P, Bleecker ER, Buhl R, Keene ON, et al. Mepolizumab for severe eosinophilic asthma (DREAM): a multicentre, double-blind, placebo-controlled trial. Lancet. 2012; 380(9842):651-9.

56. Ortega HG, Liu MC, Pavord ID, Brusselle GG, FitzGerald JM Chetta A, et al. Mepolizumab treatment in patients with severe eosinophilic asthma. N Engl J Med. 2014; 371(13):1198-207.

57. Bel EH, Wenzel SE, Thompson PJ, Prazma CM, Keene ON, Yancey SW, et al. Oral glucocorticoid-sparing effect of mepolizumab in eosinophilic asthma. N Engl J Med. 2014; 371(13):1189-97.

58. Chapman KR, Albers FC, Chipps B, Munoz X, Devouassoux G, Bergna M, et al. The clinical benefit of mepolizumab replac- 


\section{Moksliniai darbai ir apžvalgos}

ing omalizumab in uncontrolled severe eosinophilic asthma. Allergy. 2019; 74(9):1716-26.

59. Chupp GL, Bradford ES, Albers FC, Bratton DJ, Wang-Jairaj J, Nelsen LM, et al. Efficacy of mepolizumab add-on therapy on health-related quality of life and markers of asthma control in severe eosinophilic asthma (MUSCA): a randomised, doubleblind, placebo-controlled, parallel-group, multicentre, phase 3b trial. Lancet Respir Med. 2017; 5(5):390-400.

60. Castro M, Zangrilli J, Wechsler ME, Bateman ED, Brusselle GG, Bardin P, et al. Reslizumab for inadequately controlled asthma with elevated blood eosinophil counts: results from two multicentre, parallel, double-blind, randomised, placebocontrolled, phase 3 trials. Lancet Respir Med. 2015; 3(5):355-66.

61. Bakakos A, Loukides S, Bakakos P. Severe eosinophilic asthma. J Clin Med. 2019; 8(9).

62. Pelaia C, Vatrella A, Bruni A, Terracciano R, Pelaia G. Benralizumab in the treatment of severe asthma: design, development and potential place in therapy. Drug Des Devel Ther. 2018; 12:619-28.

63. Bleecker ER, FitzGerald JM, Chanez P, Papi A, Weinstein SF, Barker P, et al. Efficacy and safety of benralizumab for patients with severe asthma uncontrolled with high-dosage inhaled corticosteroids and long-acting beta2-agonists (SIROCCO): a randomised, multicentre, placebo-controlled phase 3 trial. Lancet. 2016; 388(10056):2115-27.

64. FitzGerald JM, Bleecker ER, Nair P, Korn S, Ohta K, Lommatzsch $\mathbf{M}$, et al. Benralizumab, an anti-interleukin-5 receptor alpha monoclonal antibody, as add-on treatment for patients with severe, uncontrolled, eosinophilic asthma (CALIMA): a randomised, double-blind, placebo-controlled phase 3 trial. Lancet. 2016; 388(10056):2128-41.

65. Nair P, Wenzel S, Rabe KF, Bourdin A, Lugogo NL, Kuna P, et al. Oral glucocorticoid-sparing effect of benralizumab in severe asthma. N Engl J Med. 2017; 376(25):2448-58.

66. Castro M, Corren J, Pavord ID, Maspero J, Wenzel S, Rabe KF, et al. Dupilumab efficacy and safety in moderate-to-severe uncontrolled asthma. N Engl J Med. 2018; 378(26):2486-96.

67. Rabe KF, Nair P, Brusselle G, Maspero JF, Castro M, Sher L, et al. Efficacy and safety of dupilumab in glucocorticoid-de- pendent severe asthma. N Engl J Med. 2018; 378(26):2475-85.

68. Busse WW, Maspero JF, Rabe KF, Papi A, Wenzel SE, Ford LB, et al. Liberty asthma QUEST: phase 3 randomized, doubleblind, placebo-controlled, parallel-group study to evaluate dupilumab efficacy/safety in patients with uncontrolled, moderate-to-severe asthma. Adv Ther. 2018; 35(5):737-48.

69. Harb H, Chatila TA. Mechanisms of dupilumab. Clin Exp Allergy. 2020; 50(1):5-14.

70. Dorey-Stein ZL, Shenoy KV. Tezepelumab as an emerging therapeutic option for the treatment of severe asthma: evidence to date. Drug Des Devel Ther. 2021; 15:331-8.

71. Pelaia C, Pelaia G, Crimi C, Maglio A, Gallelli L, Terracciano R, et al. Tezepelumab: a potential new biological therapy for severe refractory asthma. Int J Mol Sci. 2021; 22(9).

72. European medicines agency. Available from: https://www.ema. europa.eu/en. Accessed 27-07-2021

73. Patel SS, Casale TB, Cardet JC. Biological therapies for eosinophilic asthma. Expert Opin Biol Ther. 2018; 18(7):747-54.

74. Agache I, Song Y, Rocha C, Beltran J, Posso M, Steiner C, et al. Efficacy and safety of treatment with dupilumab for severe asthma: a systematic review of the EAACI guidelinesrecommendations on the use of biologicals in severe asthma Allergy. 2020; 75(5):1058-68.

75. Pavord ID, Chanez P, Criner GJ, Kerstjens HAM, Korn S, Lugogo N, et al. Mepolizumab for eosinophilic chronic obstructive pulmonary disease. N Engl J Med. 2017; 377(17):1613-29.

76. Brandsma CA, Van den Berge $M$, Hackett TL, Brusselle G, Timens W. Recent advances in chronic obstructive pulmonary disease pathogenesis: from disease mechanisms to precision medicine. J Pathol. 2020; 250(5):624-35.

77. Criner GJ, Celli BR, Singh D, Agusti A, Papi A, Jison M, et al. Predicting response to benralizumab in chronic obstructive pulmonary disease: analyses of GALATHEA and TERRANOVA studies. Lancet Respir Med. 2020; 8(2):158-70.

78. EU Clinical Trials. Available from: https://clinicaltrials.gov/ct $2 /$ show/NCT04456673. Accessed 27-07-2021.

79. EU Clinical Trials. Available from: https://clinicaltrials.gov/ct2/ show/study/NCT04039113. Accessed 27-07-27. 